\title{
複合材料の衝撃応答と破壊（II）
}

\author{
武 田 展 雄*
}

\section{2 弾性波動の分散}

\section{2 .1 分散とは?}

前節で述べたように応力波の代表的長さが複合材料構 成要素のサイズに近づくと，不均質性を考慮する必要が 生じ応力波の分散が問題となる．分散とは波の位相速度 $v$ が波長入に依存することであり，パルス波形は伝播に ともない変形してくる．ここで分散は応力波のエネルギ が散逸して熱に変わってしまう減衰 (attenuation, 3.3 節参照）とは異なることに注意する．弾性体中の応力波 は分散がある場合でも減衰がなければ，エネルギは保存 されその周波数成分が異なってくるだけである ${ }^{2,14)}$ ．す なわち一次元弾性波を例にとると，任意の応力波の変位 $u(x, t)$ は円振動数 $\omega(=k v=2 \pi v / \lambda)$ の調和振動成分の 重站合せ積分として次式の形に書ける。

$$
u(x, t)=\frac{1}{2 \pi} \int_{-\infty}^{\infty} A(\omega) \exp \left[-i \omega\left(t-\frac{x}{v(\omega)}\right)\right] d \omega
$$

一般に複合材料中を伝播する応力波の分散は二つに大別 できよう.一つは材料分散 (material dispersion) と呼 ぶべきもので，既述のように材料中の緎維，粒子などに 上る不均質性に起因する応力波の多重反射, 透過の結果 生じるものである。 もら一つは棒，板，シェルなどとし て複合材料を用いる場合, 有限な大きさの構造要素の境 界面での応力波の反射の結果生じるもので，構造分散 (structural dispersion) とも呼べよう. 後者は当然等方 性弾性体でも存在する. 実際の複合材料構造では, 応力 波の波長が短い場合には材料分散, 構造分散両者を考虑 する必要がある. 以下材料分散について考えるが，構造 分散は波動伝播実験において重要であり (3.4 節), 詳細

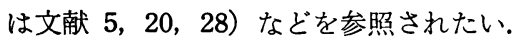

\subsection{2 積層弾性体中の応力波の透過と反射}

図 3 に示した積層弾性体を例にとって積層垂直方向 （ $x_{2}$ 軸方向）に伝播する応力波を考之よう. 3.1 節で扱

* Nobuo TAKEDA : 九州大学応用力学研究所 - 九州 大学大学院総合理工学研究科高エネルギー物質科 学専攻
ったような波長が長いと仮定する均質異方性体としての 取扱いができる場合, 縦波, 横波速度 $v_{L}, v_{T}$ はおのお の次式で与えられる.

$$
\begin{gathered}
v_{L}{ }^{2}=\frac{\left(d_{f}+d_{m}\right)^{2}}{\left[d_{f} /\left(\lambda_{f}+2 \mu_{f}\right)+d_{m} /\left(\lambda_{m}+2 \mu_{m}\right)\right]\left(d_{f} \rho_{f}+d_{m} \rho_{m}\right)} \\
v_{T}{ }^{2}=\frac{\left(d_{f}+d_{m}\right)^{2}}{\left(d_{f} / \mu_{f}+d_{m} / \mu_{m}\right)\left(d_{f} \rho_{f}+d_{m} \rho_{m}\right)}
\end{gathered}
$$

一方, もら一つの極端な場合として波長が短く， 2 種 類の材料中をおのおのの弾性波速度で応力波が伝播する 場合を考兄よう。この場合, 当然異種材料境界面では応 力波の反射，透過が生じる。いま材料 $m$ と $f$ との境界面 飞 $m$ から $f$ に入射する横波（応力值 $\sigma_{i}$ ) を考穴ると，境 界面での力および粒子速度の連続条件から透過波 $\left(\sigma_{t}\right)$, 反射波 $\left(\sigma_{r}\right)$ は次式で与えられる13).

$$
\begin{gathered}
\frac{\sigma_{t}}{\sigma_{i}}=\frac{2 \sqrt{\rho_{f} \mu_{f}}}{\sqrt{\rho_{f} \mu_{f}}+\sqrt{\rho_{m} \mu_{m}}} \\
\frac{\sigma_{r}}{\sigma_{i}}=\frac{\sqrt{\rho_{f} \mu_{f}}-\sqrt{\rho_{m} \mu_{m}}}{\sqrt{\rho_{f} \mu_{f}}+\sqrt{\rho_{m} \mu_{m}}}
\end{gathered}
$$

絽波の場合は $\mu$ を $\lambda+2 \mu$ で置き換えればよい、 $\sqrt{\rho \mu}$

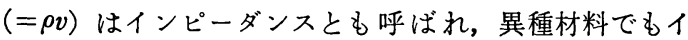
ンピーダンスが等しければ入射波は反射せずすべて透過 する.インピーダンスが異なることにより応力波の反射 が生じる. 図3のように境界面が多数ある場合には上述 の反射, 透過が繰り返され, 系全体は複雑な応答を示 す ${ }^{29}$. いま, 2 種類の材料中の弾性波速度から横波の最 高伝播速度を計算する。

$$
v_{T}^{M}=\left(d_{f}+d_{m}\right) / \Delta t
$$

ここで $\Delta t$ は各層の弾性波速度から,

$$
\Delta t=\frac{d_{f}}{\sqrt{\mu_{f} / \overline{\rho_{f}}}}+\frac{d_{m}}{\sqrt{\mu_{m} / \rho_{m}}}
$$

上 2 式から，

$$
v_{T} M=\frac{\sqrt{\mu_{f} \mu_{m} / \rho_{f} \rho_{m}}\left(d_{f}+d_{m}\right)}{d_{f} \sqrt{\mu_{f} / \rho_{f}}+d_{m} \sqrt{\mu_{m} / \rho_{m}}}
$$

となる．縦波についても同様である（40)式と（43）式を 
比較すると, $v_{T}^{M}$ が $v_{T}$ より大きいことが証明できる.

以上二つの極端な場合について応力波の位相速度を求 め，その值が異なることがわかった．この二つの場合の 間を埋めるべく波長の関数としての位相速度すなわち分 散関係が存在する.

\section{2 .3 分散関係の厳密解}

前項と同じく図3を例にとって $x_{2}$ 軸方向（簡単 のため以下 $x_{2}$ を $x$ で表わす）に伝播する平面調和振 動波の分散関係に対する弾性論による厳密解を求めよ $\zeta^{13,30,31)}$. まず運動方程式は,

$$
C_{n} \frac{\partial^{2} u_{n}}{\partial x^{2}}=\rho_{n} \frac{\partial^{2} u_{n}}{\partial t^{2}}, \quad n=m, f
$$

である.ここで縦波では $C_{n}=\lambda_{n}+2 \mu_{n}$, 横波では $C_{n}=\mu_{n}$ であり, 変位 $u_{n}$ は絎波では伝播方向, 横波で はそれに垂直方向のものである.さて次式で与えられる 解を考えよう。

$$
\begin{aligned}
u_{n}(x, t) & =U_{n}(x) \exp \left[i \omega\left(t+\frac{x}{v}\right)\right] \\
& =U_{n}(x) \exp [i(\omega t+k x)]
\end{aligned}
$$

ここで $U_{n}(x)$ は周期性から次のように仮定する.

$$
U_{n}\left(x+d_{m}+d_{f}\right)=U_{n}(x)
$$

ところで(44) 式の解は, 2 種類の材料の弾性波速度 $v_{n}$ $\left(=\sqrt{C_{n} / \rho}\right)$ を用いて次の形で与えられるから，

$$
\exp \left[i \omega\left(t \pm \frac{x}{v_{n}}\right)\right]
$$

$U_{n}(x)$ の一般解は $A_{n}, B_{n}$ を複素定数として,

$$
\begin{aligned}
& U_{n}(x)=A_{n} \exp \left(i \alpha_{1} x\right)+B_{n} \exp \left(i \alpha_{2} x\right) \\
& \alpha_{1}=-\omega / v+\omega / v_{n}, \alpha_{2}=-\omega / v-\omega / v_{n}
\end{aligned}
$$

となる. 次に (47) 式の周期性より次式が成立しなければ ならない.

$$
\left.U_{m}(x)\right|_{x=d_{m}}=\left.U_{f}(x)\right|_{x=-d_{f}}
$$

また応力の周期性より，

$$
\left.C_{m} \frac{\partial u_{m}}{\partial x}\right|_{x=d m}=\left.C_{f} \frac{\partial u_{f}}{\partial x}\right|_{x=-d_{f}}
$$

$x=0$ における変位, 応力の連続性より

$$
\begin{gathered}
\left.U_{m}(x)\right|_{x=0}=\left.U_{f}(x)\right|_{x=0} \\
\left.C_{m} \frac{\partial u_{m}}{\partial x}\right|_{x=0}=\left.C_{f} \frac{\partial u_{f}}{\partial x}\right|_{x=0}
\end{gathered}
$$

(49)～(52) 式は四つの未定定数 $A_{m}, B_{m}, A_{f}, B_{f}$ に関 する四つの条件式を与える. 係数行列式を 0 とおくこと により次の分散関係式が得られる.

$$
\cos \frac{\omega\left(d_{f}+d_{m}\right)}{v}=\cos \frac{\omega d_{m}}{v_{m}} \cos \frac{\omega d_{f}}{v_{f}}
$$

$$
-\chi \sin \frac{\omega d_{m}}{v_{m}} \sin \frac{\omega d_{f}}{v_{f}}
$$

ここで,

$$
\chi=\left(\rho_{m} C_{m}+\rho_{f} C_{f}\right) / 2 \sqrt{\rho_{m} \rho_{f} C_{m} C_{f}}
$$

さて(53) 式で与えられる位相速度 $v$ が，波長が大すな わち $\omega \cong 0$ で(39)，（40) 式の有効弾性率を用いた均質弾 性体中の弾性波速度に等しくなることを示そう。まず を $\omega$ で級数展開して,

$$
v=v_{0}+\frac{\alpha}{2} \omega^{2}+\cdots
$$

とし，(53) 式を $\omega$ で級数展開して $O\left(\omega^{2}\right)$ の項までとる 之,

$$
\frac{\omega^{2}\left(d_{f}+d_{m}\right)^{2}}{v_{0}^{2}}=\frac{\omega^{2} d_{m}^{2}}{v_{m}^{2}}+\frac{\omega^{2} d_{f}^{2}}{v_{f}^{2}}+2 \chi \frac{\omega^{2} d_{m} d_{f}}{v_{m} v_{f}}
$$

となり， $v_{0}$ は縦波，横波に対しておのおの(39)，(40)式 と同じであることがわかる. 次に(53)式の級数展開を $O\left(\omega^{4}\right)$ の項までとり，(56)式の結果を用いると(55)式中 の $\alpha$ は

$$
\alpha=\frac{v_{0}^{3} d_{m}^{2} d_{f}^{2}}{3\left(d_{m}+d_{f}\right)^{2} v_{m}^{2} v_{f}^{2}}\left(1-\chi^{2}\right)
$$

と求まる.（54）式から $\chi \geqq 1$ であるから(55)，(57)式よ り $\omega$ が小さい範囲では $\omega$ が増すにしたがい位相速度 $v$ は減少してくることがわかる.

また積層方向（図 3 の $x_{1}$ 軸方向）に伝播する縦波， 粒子運動方向が $x_{3}$ 軸, $x_{2}$ 軸方向である水平偏向, 垂直 偏向の横波（おのおの SH 波, SV 波とも呼ぶ）につい ても同様な厳密解が求められている ${ }^{13,30,31)}$.

\subsection{4 有効剛性理論による分散関係}

分散関係の厳密解は図 3 のような積層体については求 められているが，図2のような繊維強化複合材料のモデ ルについて求めるのは困難である. このため何らかの近 似理論が必要となり，いくつかの理論が提案されている (3.2.5 項参照). その代表例として最も研究が進んでい る Achenbach, Herrmann, Sun らによって提唱された 有効剛性理論 (effective stiffness theory) を紹介しよ $5^{8,11,31,32)}$. 全体を均質異方性弾性体と考元る有効弾性 率理論とは異なり，2種類の弾性体の弾性率と幾何学的 形状を組み合わせて, 弾性波の分散挙動も記述できる近 似的な有効剛性を導いている。

厳密解と比較するため，ここでも図 3 の積層体を考え よう（図 2 に示すような一方向㵶維強化複合材料につい ても有効剛性理論による分散関係が求められている(8)). 


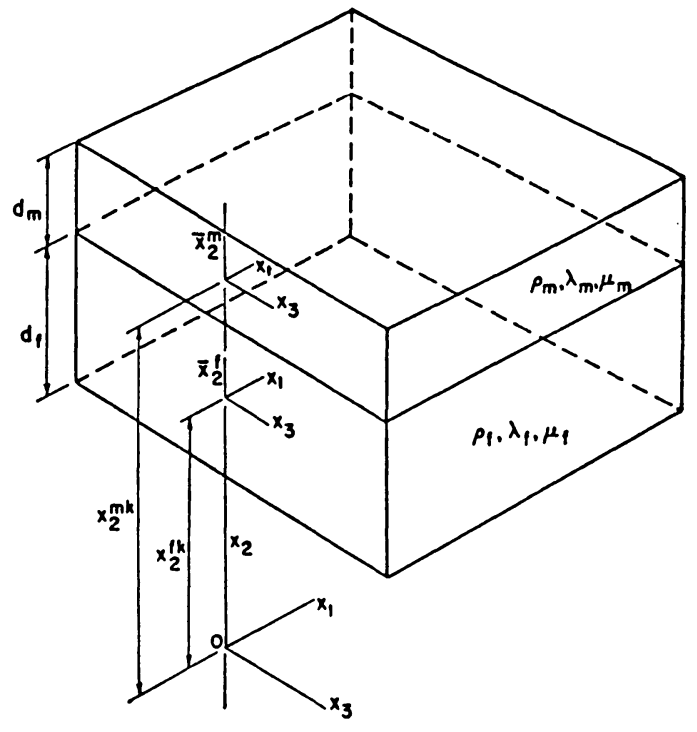

図 11 積層体中の繰返しニニットと局所座標系 ${ }^{31)}$

まず板の近似理論でよく用いられるよらに，積層体中の $k$ 番目の $f, m$ の組（図 11）に対する二つの局所座標 系 $\left(x_{1}, \bar{x}_{2} f, x_{3}\right),\left(x_{1}, \bar{x}_{2}{ }^{m}, x_{3}\right)$ を用いて, おのおのの 変位 $u_{i}{ }^{f k}, u_{i}{ }^{m k}(i=1,2,3)$ をルジャンドル多項式で 展開する.すなわち $k$ 番目の $f$ 層については（ $m$ 層も 同様),

$$
u_{i} f k=\sum_{n=0}^{\infty} P_{n}\left(\bar{x}_{2}^{f} / d_{f}\right) u_{n i} f k\left(x_{1}, x_{2}^{f k}, x_{3}, t\right)
$$

ここで,

$$
\begin{aligned}
& P_{0}\left(\bar{x}_{2} f / d_{f}\right)=1, P_{1}\left(\bar{x}_{2} f / d_{f}\right)=\bar{x}_{2} f / d_{f} \\
& P_{2}\left(\bar{x}_{2} f / d_{f}\right)=\left[3\left(\bar{x}_{2} f / d_{f}\right)^{2}-1\right] / 2, \cdots
\end{aligned}
$$

いま各層の厚さ $d_{f}, d_{m}$ は積層体全体の寸法（厚さな ぞ）や波長に比べ小さく（58)式において線形項までと る（高次項までとった改良はたとえば文献 12，33）を 参照）と,

$$
u_{i}^{f k}=u_{0 i}^{f k}\left(x_{1}, x_{2}^{f k}, x_{3}, t\right)+\bar{x}_{2} f \psi_{2 i}^{f k}\left(x_{1}, x_{2}^{f k}, x_{3}, t\right)
$$

$$
u_{i}^{m k}=u_{0 i}^{m k}\left(x_{1}, x_{2}^{m k}, x_{3}, t\right)+\bar{x}_{2}^{m} \psi_{2 i}^{m k}\left(x_{1}, x_{2}^{m k}, x_{3}, t\right)
$$

が得られる. (60) 式で $u_{0 i}{ }^{f k}$ は $k$ 番目の $f$ 層中央面にお ける变位を表わし, $\phi_{21}{ }^{f k}, \phi_{23}{ }^{f k}$ は厚さ方向の反対称剪 断変形を, $\phi_{22}{ }^{f k}$ は厚さ方向の対称伸縮変形を表わす. $f$ 層と $m$ 層との境界面での変位の連続性より

$$
\begin{gathered}
u_{0 i}{ }^{m k}\left(x_{1}, x_{2}^{m k}, x_{3}, t\right)-u_{0 i}^{f k}\left(x_{1}, x_{2}^{f k}, x_{3}, t\right) \\
=\frac{1}{2} d_{f} \psi_{2 i}^{f k}\left(x_{1}, x_{2}^{f k}, x_{3}, t\right)
\end{gathered}
$$

$$
+\frac{1}{2} d_{m} \psi_{2 i}^{m k}\left(x_{1}, x_{2}^{m k}, x_{3}, t\right)
$$

ただし境界面での応力の連続性は課さないことにする.

次にこの変位を用いて歪ェネルギおよび運動エネルギ を計算する．等方性弾性体中の昰エネルギ密度 $W$ は

$$
W=\frac{1}{2} \lambda \varepsilon_{i i} \varepsilon_{j j}+\mu \varepsilon_{i j} \varepsilon_{i j} \quad(i, j=1,2,3, \quad \text { 総和規約 })
$$

で与えられる. $k$ 番目の $f$ 層内の歪エネルギ密度の近 似値は次のように求められる。まず(60)式を(5)式に代 入して歪テンソル成分を求める. ただし $x_{2}$ 軸方向の微 分は局所座標軸 $\bar{x}_{2} f$ で置き換える. 得られた $\varepsilon_{i j}$ を(63) 式に代入して $\bar{x}_{2} f=-d_{f} / 2 \sim d_{f} / 2$ にわたり積分する と, 単位表面積あたりの歪エネルギ $W^{f k}$ が求まる. 同 様に $k$ 番目の $m$ 層についての $W^{m k}$ 女求められる. 一 方, 等方性弾性体中の運動エネルギ密度 $T$ は, 密度 $\rho$ を 用いて

$$
T=\frac{1}{2} \rho\left[\left(\frac{\partial u_{1}}{\partial t}\right)^{2}+\left(\frac{\partial u_{2}}{\partial t}\right)^{2}+\left(\frac{\partial u_{3}}{\partial t}\right)^{2}\right]
$$

で与えられる.（60)式を(64)式に代入して $k$ 番目の $f$ 層 内の単位表面積あたりの運動エネルギ $T^{f k}$ を求める と,

$$
\begin{aligned}
T^{f k}= & \sum_{i=1}^{3}\left\{\frac{1}{2}\left(d_{f}+d_{m}\right) \eta \rho\left(\frac{\partial u_{0 i} f k}{\partial t}\right)^{2}\right. \\
& \left.+\frac{1}{2}\left(d_{f}+d_{m}\right) I_{f}\left(\frac{\partial \psi_{2 i} f k}{\partial t}\right)^{2}\right\}
\end{aligned}
$$

ただし $\rho_{f}$ は $f$ 層の密度であり，

$$
\eta=d_{f} /\left(d_{f}+d_{m}\right), \quad I_{f}=\frac{1}{12} d_{f}^{2} \eta \rho_{f}
$$

同様に $T^{m k}$ も(65), (66) 式において添字 $f, m$ をおの おの $m, f$ で置き換えることにより求められる.

さて図 3 において $x_{2}$ 軸方向のある長さ $l$ 内におのお の $n$ 個の $f, m$ 層を含むとすると， $x_{1}, x_{2}, x_{3}$ 軸方向 に長さ $1, l, 1$ をもつ直方体中に蓄えられる歪エネル ギ，運動エネルギはおのおの次式で与えられる。

$$
W_{l}=\sum_{k=1}^{n}\left(W^{f k}+W^{m k}\right), \quad T_{l}=\sum_{k=1}^{n}\left(T^{f k}+T^{m k}\right)
$$

有効剛性理論の基本的な仮定は, この $2 n$ 個の点 $x_{2}{ }^{f k}$, $x_{2}{ }^{m k}(k=1, \cdots, n)$ での值の和としての (67) 式が，連続変 数 $x_{2}$ を用いた重み付き積分によって近似できるとする ことにある.すなわち，

$$
W_{l} \cong \int_{l} \frac{1}{d_{f}+d_{m}}\left(W^{f}+W^{m}\right) d x_{2},
$$




$$
T_{l} \cong \int_{l} \frac{1}{d_{f}+d_{m}}\left(T^{f}+T^{m}\right) d x_{2}
$$

ただし(68)式の右辺で上添字 $k$ は除かれ， $W^{f}, W^{m}, T^{f}$, $T_{m}$ はすべての $x_{2}$ に対して定義される。新しい歪エネ ルギ, 運動エネルギは $x_{1}, x_{2}, x_{3}, t$ の連続関数として,

$$
\left.\begin{array}{l}
W=\left[W^{f}\left(x_{i}, t\right)+W^{m}\left(x_{i}, t\right)\right] /\left(d_{f}+d_{m}\right) \\
T=\left[T^{f}\left(x_{i}, t\right)+T^{m}\left(x_{i}, t\right)\right] /\left(d_{f}+d_{m}\right)
\end{array}\right\}
$$

となり， $x_{2}=x_{2} f k$ または $x_{2}=x_{2}^{m k}$ のみで定義されてい た変数 $u_{0 i}{ }^{f k}, u_{0 i}{ }^{m k}, \phi_{2 i}{ }^{f k}, \phi_{2 i}{ }^{m k}$ \& $x_{2}$ に関する連続 関数となるので上添字 $k$ は除く。また変位の連続条件 (62) 式も $x_{2}$ の連続関数を用いて,

$$
\begin{aligned}
S_{i} \equiv & \left(d_{f}+d_{m}\right) \frac{\partial u_{i}\left(x_{j}, t\right)}{\partial x_{2}}-d_{f} \psi_{2 i} f\left(x_{j}, t\right) \\
& +d_{m} \psi_{2 i}{ }^{m}\left(x_{j}, t\right)=0
\end{aligned}
$$

となる。ここで $u_{0 i}{ }^{f}, u_{0 i}{ }^{m}$ は同じ変位 $u_{i}$ で表わすが， 局所的な変形を表わす $\psi_{2 i}{ }^{f}, \psi_{2 i}{ }^{m}$ は別々の関数として 残す. 以上のようにして図 3 の繰返乙積層体は九つの連 続関数 $u_{i}, \psi_{2 i}{ }^{f}, \psi_{2 i}{ }^{m}(i=1,2,3)$ で表わされる均質弾性 体に置換される.

$u_{i}, \psi_{2 i}{ }^{f}, \psi_{2 i}{ }^{m}$ に関する運動方程式を導出すべく, 直

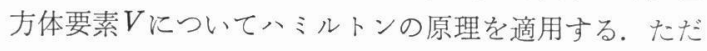
し外力による仕事は無視する.

$$
\delta \int_{t_{0}}^{t_{1}} \int_{V}(T-W) d x_{1} d x_{2} d x_{3} d t=0
$$

(70)式の変位の連続条件を付帯条件としてラグランジュ の未定乗数 $\lambda_{i}$ を用いて変分表示のなかに導入すると ${ }^{34)}$,

$$
\delta \int_{t_{0}}^{t_{1}} \int_{V}\left(T-W-\lambda_{1} S_{1}-\lambda_{2} S_{2}-\lambda_{3} S_{3}\right) d x_{1} d x_{2} d x_{3} d t=0
$$

この式から運動方程式としてのオイラーの方程式を求め ると,

$$
\begin{gathered}
\sum_{r=1}^{4} \frac{\partial}{\partial q_{r}}\left[\frac{\partial\left(T-W-\lambda_{1} S_{1}-\lambda_{2} S_{2}-\lambda_{3} S_{3}\right)}{\partial\left(\partial f_{s} / \partial q_{r}\right)}\right. \\
\left.-\frac{\partial\left(T-W-\lambda_{1} S_{1}-\lambda_{2} S_{2}-\lambda_{3} S_{3}\right)}{\partial f_{s}}\right]=0
\end{gathered}
$$

ここで $f_{s}$ は 12 個の変数 $u_{i}, \psi_{2 i}{ }^{f}, \psi_{2 i}{ }^{m}, \lambda_{i}$ を表わし, $q_{r}$ は位置, 時間の座標軸 $x_{i}, t$ を表わす。 (69), (70) 式を (73)式に代入することにより 12 個の運動方程式が得ら れる. 3.2 .3 項と同様に変位に平面調和振動波解を仮定 することにより，有効剛性理論による分散関係が求めら れる。

たとえば図 3 の $x_{2}$ 軸方向に伝播する横波を考えよ
う. $x_{2}$ 軸を対称軸とする面内等方性から，ここでは $x_{1}$ 軸方向の粒子運動を考えることにして，0でない変数 4 個を次式で仮定する.

$$
\begin{aligned}
& \left(u_{1}, \phi_{21} f, \psi_{21}{ }^{m}, \lambda_{1}\right) \\
& \quad=\left(A_{1}, A_{21} f, A_{21}{ }^{m}, B_{1}\right) \exp \left[i k\left(x_{2}-v t\right)\right]
\end{aligned}
$$

(74) 式を(73)式に代入すると $A_{1}, A_{21}{ }^{f}, A_{21}{ }^{m}, B_{1}$ に関 する四つの同次方程式が得られるので, その係数行列式 を0とおくことにより次の無次元化した分散関係式が導 かれる。

$$
\begin{aligned}
& \left\{\theta \xi^{4}+12 \eta[(1-\eta)+\eta \theta]^{2} \xi^{2} /(1-\eta)\right\} \beta^{4} \\
& \quad-\left\{12\left[\gamma+\theta \eta^{2} /(1-\eta)^{2}\right] \xi^{2}\right. \\
& \left.\quad+144 \eta^{2}[(1-\eta)+\eta \theta][(1-\eta) \gamma+\eta] /(1-\eta)^{2}\right\} \beta^{2} \\
& \quad+144 \eta^{2} \gamma /(1-\eta)^{2}=0
\end{aligned}
$$

ここで,

$$
\beta=v /\left(\mu_{m} / \rho_{m}\right)^{1 / 2}, \quad \xi=k d_{f}, \quad \theta=\rho_{f} / \rho_{m}, \quad \gamma=\mu_{f} / \mu_{m}
$$

$\xi \rightarrow 0$ すなおち $\omega \rightarrow 0$ において(75)式は(40), (56) 式に 㷌着することに注意する。

\section{2 .5 分散関係の例}

$3.2 .3,3.2 .4$ 項で求めた分散関係の厳密解 (TE) と有 効剛性理論による近似解 (EST) とをいくつか比較して みよう. ただし $\eta=0.8, \theta=3$, ポアソン比 $\nu_{f}=0.3$, $\nu_{m}=0.35$ として $r=100,50,10$ の 3 種類に対して示 す. 表示には(76)式の無次元化量を用いる.

まず図 12 に積層垂直方向に伝播する横波の最低次モ ードの分散関係を示す. TE ((53)式), EST ((75)式) ともに $\xi \rightarrow 0$ では分散のない有効弾性率理論による解 (EMT) に一致する. TE とはかなり離れてしまう。図 13 は積層方向に伝播

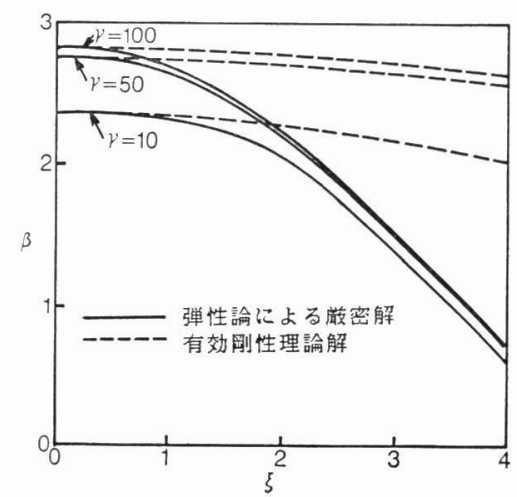

図 12 積層垂直方向に伝播する横波最低次モードの 分散関係 ${ }^{31}$ 


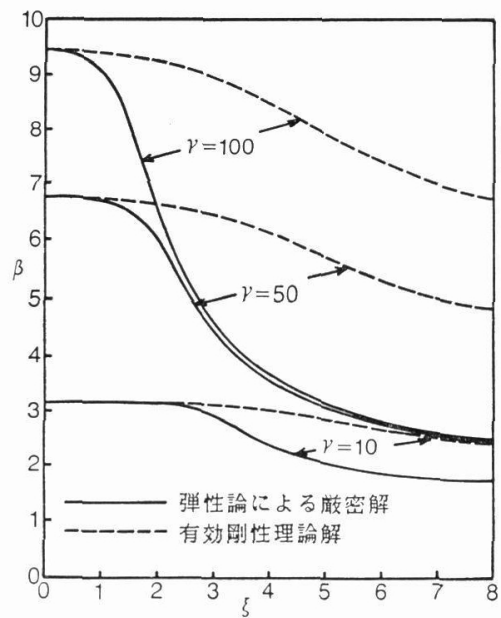

図 13 積層方向に伝播する咣波最低次モードの分散 関係 ${ }^{31)}$

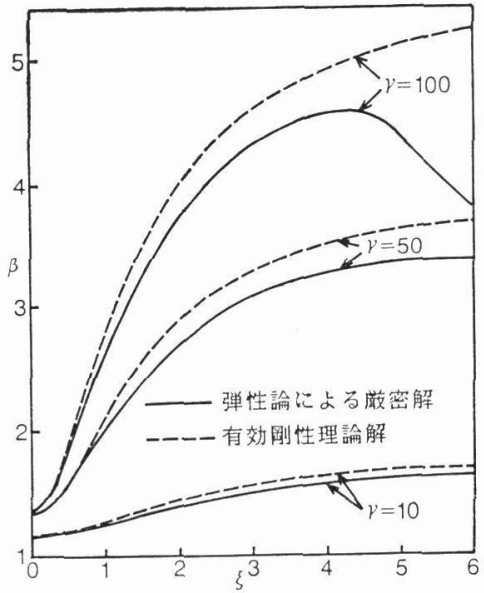

図 14 積層方向に伝播する SV 波最低次モードの分 散関係 ${ }^{31}$

する縦波の最低次モードについてであるが，図 12 と同 様のことがいえる. ただし $r=100$ では TE と EST とは $0<\xi<1$ の範用でのみよく一致する，図 14 は積層 方向伝播の SV 波の最低次モードであるが，乡が小さい 範囲でもとくに からはかなり異なる. TE と EST との一致は $\xi<4$ 程 度まではかなりよい。

積層体や繊維強化複合材料の波動分散関係を記述する ための近似理論は, 有效剛性理論 ${ }^{31-33)}$ 以外にも各種の混 合理論 (mixture theories) ${ }^{9,35,36)}$, 変分原理に基づく理

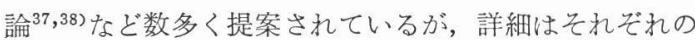

文献およびレビュー2,6-13) を参照されたい、また以上調 和振動波のみを扱ってきたが，ステップ状，パルス状の 弾性波動については省略する。原理上は任意波形もフー リエ展開すれば調和振動波の重祆合せとして扱えるはず であるが，解析が困難となるため格子モデル ${ }^{39}$ 粘弾性相 似モデル40,41)を用いるか，波頭のみに着目した波頭近似 法 (head-of-the pulse approximation) ${ }^{42-44)}$ やその他の 近似法 ${ }^{36,45,46)}$ 用いるかして近似計算が行なわれてい る.

\section{3 減衰}

応力波の減衰はエネルギの損失を表わし，变形した応 力波内にエネルギが再分布されエネルギは保存される分 散現象之は異なる。複合材料中を伝播する応力波のエ亦 ルギ損失の原因としては少なくとも次の四つの現象が考 壳られる2).

（i）応力波の散乱 (scattering)ーランダムな不均質 性の場合

（ii） 構成材料の粘弾性，塑性変形

(iii) 微視的破壊

(iv) 構成材料間接着不良部に扮沙る摩擦

まず応力波の散乱は，3.2 節で扱った戍 2 や図 3 のよ らな構成材料が周期的な配列をもつ複合材料や積層体で も生じている。 しかし，その周期性のため散乱エネルギ は応力波に再び戻されてエネルギは保存される(分散).

一方，構成材料がランダムな配列，不均質性をもつ場 合，散乱されたエネルギは応力波には戻されずみかけ上 減衰を生じる $2,13,47-49)$ ，たと放ば剛体球粒子分散複合材 料で分散粒子の体積含有率 $c$ が小さく $(c<0.10)$, ラン ダム分散している場合, 波長が粒子径に比べ長ければ, 弾性体中に一つの粒子のみが存在する図 15 のモデルで 表わすことができる ${ }^{2,13)}$ ，混合理論を用いた運動方程式 は粒子および粒子がないときのマトリックスの変位 $u_{i}$, $u_{m}$ を用いて次式で表わさ机る（記号は図 15 参照）。

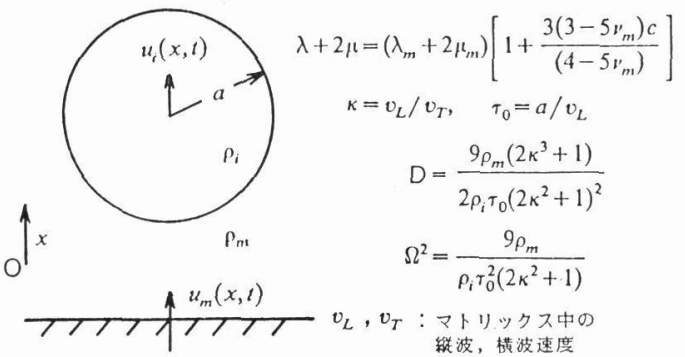

図 15 剛体球による応力波の散乱 ${ }^{13)}$ 


$$
\left.\begin{array}{l}
\frac{\partial^{2} u_{i}}{\partial t^{2}}+2 D\left(\frac{\partial u_{i}}{\partial t}-\frac{\partial u_{m}}{\partial t}\right)+\Omega^{2}\left(u_{i}-u_{m}\right)=0 \\
\rho_{m}(1-c) \frac{\partial^{2} u_{m}}{\partial t^{2}}-(\lambda+2 \mu) \frac{\partial^{2} u_{m}}{\partial x^{2}}=-\rho_{i} c \frac{\partial^{2} u_{i}}{\partial t^{2}}
\end{array}\right\}
$$

いま

$$
\left.\begin{array}{l}
u_{i}(x, t)=U_{i} \exp [i(\zeta x-\omega t)], \\
u_{m}(x, t)=J_{m} \exp [i(\zeta x-\omega t)] \\
\zeta=\zeta_{1}+i \zeta_{2} \quad\left(\zeta_{1}, \zeta_{2}: \text { 実数 }\right)
\end{array}\right\}
$$

と新き(77)式に代入して $U_{i}, U_{m}$ の係数行列式を 0 と おくと, $\omega$ の関数としてのらが求まる.これから位相速 度 $v=\omega / \zeta_{1}$ が求まる (分散関係).

$$
\left.\begin{array}{l}
v^{2}=v_{0}^{2}\left[1-\left(\frac{\omega}{\Omega}\right)^{2} \frac{c \rho_{i}}{\rho_{\text {MEAN }}}\right] \\
v_{0}^{2}=\frac{\lambda+2 \mu}{\rho_{\text {MEAN }}}, \rho_{\text {MEAN }}=\rho c_{i}+(1-c) \rho_{m}
\end{array}\right\}
$$

一方， $\zeta_{2}$ は (78) 式で $\exp \left(-\zeta_{2} x\right)$ 項を通して波の減衰を 支配する.

$$
\zeta_{2}=\frac{\rho_{i}}{\rho_{\mathrm{MEAN}}}\left(\frac{\rho_{i}}{\rho_{m}}\right)^{2} \frac{c}{2 v_{0}}\left(\frac{2 \kappa^{3}+1}{9}\right) \tau_{0}{ }^{3} \omega^{4}
$$

$\zeta_{2}$ が $\omega^{4}$ に比例することはよく知られたレイリ一散乱則 (Rayleigh scattering law) と同様である.

次に, マトリックスに高分子材料を用いる場合はその 粘弾性特性を考慮する必要があろう。調和振動波 ${ }^{50,51)}$ お よびステップ状波 ${ }^{52)}$ につて分散, 減衰が求められてい るが，ここでは積層板（図３）の積層方向に伝播する綎 波の最低次モードについての結果の例 ${ }^{51)}$ みを図 16 に 示す.ただし 3.2 .5 項に合わせて， $\theta=3 ， \nu_{f}=0.3, \nu_{m}$ $=0.35, \gamma=100, \eta=0.2,0.5,0.8$ とし, マトリックス の粘弾性特性值は代表的なものを用いた。粘弾性波の位 相速度は弾性波より大きいこと，位相速度が減少してく る振動数域で減衰率が増加することなどがわかる.

積層板中の接着破壊部を考慮した波動解析もDrumheller ら ${ }^{53,54)}$ によってなされている.

\section{4 波動伝播実験}

複合材料中の波動伝播実験は実験装置，方法の研究開 発と密接に結びついており, 理論解析の発展よりかなり 遅れているといえよう。しかし, 理論解析モデルの妥当 性を調べるべく数々の波動伝播実験が最近くふうされて きている。

最も簡単な例として 3.1 節で扱った分散のない有効弾 性率理論による応力波の伝播速度を求める力法を挙げよ 5. この場合伝播速度が求まれば有効弾性率もすぐ求ま
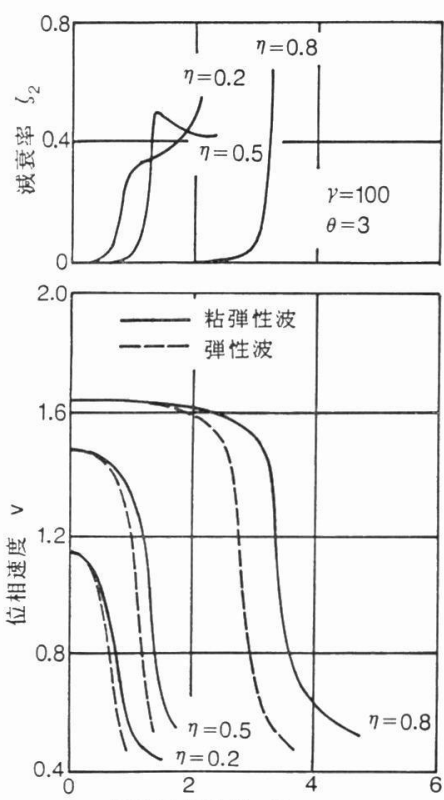

無次元振動数 $\Omega$

図 16 粘弾性マトリックス層を有する繰返し積層体 に打る積層方向に伝播する縦波最低次モー ドの減衰と分散 ${ }^{51)}$

$\Omega=\omega\left(d_{f}+d_{m}\right) / v_{T} f\left(v_{T} f: f\right.$ 層中の横波速 度)

る. 与えられる応力波の立上り部の長さや波長が複合材 料構成要素のサイズよりかなり大きいことが必要条件で ある. いま細長い棒中の一次元波を考光ると，軸方向の 縦波速度は軸方向のヤング率 $E$ を用いて, $v_{L}=\sqrt{ } E / \rho$ と表わされる。 $v_{L}$ は棒に接着された歪ゲージを用いて

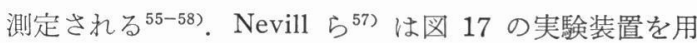
い正方形配列の一方向スチールワイヤ強化ェポキシ材の 強化方向および強化垂直方向の $v_{L}$ より両方向のヤング 率をワイヤ含有率の関数として求め ${ }^{58)}$, 複合則, HalpinTsai 則17)とよく一致する結果を得た．次に 3.1.4 項で 取りあげた板中の二次元波の実験例を挙げよう，板の表

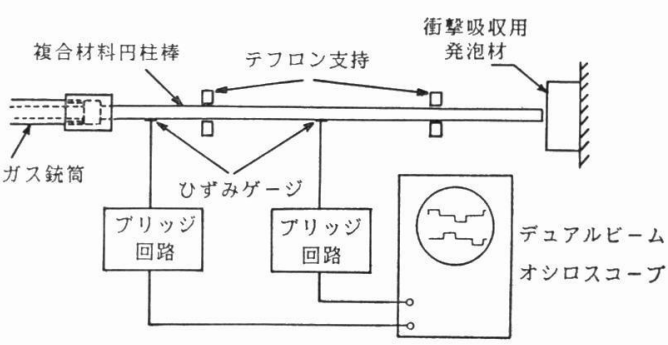

図 17 細長い棒中の一次元縦波伝播速度の測定 ${ }^{57)}$ 
裏および中央面（複合材料製作時に埋め込む）の歪ゲー ジを用いて横衝撃を受けた板中の面内波および面外曲げ 波のいくつかが測定されて扣り ${ }^{59,60)}$, 表 2 に示すように 積層板理論解との一致はよい. 丕ゲージを用いる上述の 実験法は応力波の減衰測定にも使われている

さて，応力波の分散を考慮しなければならないよらな 波長の短い応力波に対する波動伝播実験の方法は波形, 振幅により次の三つに大別できよう ${ }^{12)}$.すなわち，(1)小 振幅調和振動波 (超音波), (2)小振幅過渡波, (3)大振幅過 渡波である。

第一に超音波法は複合材料に限らず最も広く利用され ており，数多くの方法がくふうされている. 超音波法の 詳細は文献 61-63）を参照されたい。ここでは代表的な

表 2 横衝撃を受けた複合材料板中の応力波伝播速度

\begin{tabular}{|c|c|c|c|}
\hline \multirow{2}{*}{$\begin{array}{l}\text { 波のタ } \\
\text { イプ }\end{array}$} & \multicolumn{2}{|c|}{$\begin{array}{c}\text { 応力波伝播速度 } \\
(\mathrm{m} / \mathrm{s})\end{array}$} & \multirow{2}{*}{ 複合材料の種類 } \\
\hline & 実験值 & 理論値* & \\
\hline$v_{x x L} * *$ & 4050 & 4090 & \multirow{4}{*}{$\begin{array}{l}{\left[\left(0^{\circ}\right)_{5} /\left(90^{\circ}\right)_{5} /\left(0^{\circ}\right)_{5}\right.} \\
\text { glass/epoxy }\end{array}$} \\
\hline$v_{x x F^{* *}}$ & 1340 & 1520 & \\
\hline$v_{y y L}$ & 3170 & 3270 & \\
\hline$v_{y y F}$ & 1140 & 1380 & \\
\hline$v_{x \times L}$ & 3520 & 3310 & \multirow{4}{*}{$\begin{array}{l}{\left[\left(0^{\circ}\right)_{2} / \pm 45^{\circ}\right]_{2} S} \\
\text { boron/epoxy }\end{array}$} \\
\hline$v_{x \times F}$ & 1810 & 1650 & \\
\hline$v_{y y F}$ & 6970 & 7750 & \\
\hline$v_{y y} F$ & 1900 & 1650 & \\
\hline
\end{tabular}

* 積層板理論による解, ** $L$ : 縦波, $F$ : 曲げ波
方法とその結果を例示する. 超音波法の基本原理は, 試 験片の一端に取り付けられた振動子（水晶などの圧電変 換素子, PZTなどの電歪変換素子が用いられる) に有限 または半無限時間にわたり調和振動電気信号を送り, 振 動子を通して試験片中に超音波を発生させ, 試験片中を 一回または何回か通過した後同一かもら一つの振動子に より超音波を検出することである，通過時間や振幅を正 確に測定することにより超音波伝播速度, 減衰などが求 められる. 超音波法で注意すべき点は伝播速度の測定で ある、すなわら分散がある場合位相速度と群速度とは異 なるが，どちらの速度を測定しているのかを明確に知る 必要がある. Tauchert ら ${ }^{21)}$ は㘠 18(a) に示すように固 体バッファーを用い, パルス状超音波の通過時間を測定 することにより, 群速度を共振振動数の異なる数組の振 動子について求めた. 最も分散の大きい繊維方向伝播横 波の分散関係測定例を図 18(b) に示す. Sutherland ら ${ }^{64)}$ も同様の方法であるが，液体バッファーと一つの広帯域 振動子のみを用いており，位相速度を測定している。そ の測定例 (図 19) ${ }^{65}$ は混合理論による解とよく一致して いる. 以上のパルス超音波法は一般に音速測定の誤差が 大きくなりがちなため, 位相を正確に測定する目的で受 波パルスを他の信号と干渉させるパルス波干渉法が用い られることも多い. Whittier ら ${ }^{66)}$ は Asay ら ${ }^{67)}$ の二重 パルス波干渉法（図 20(a)）により繊維方向伝播縱波の 分散関係（図 20(b)）を求めている. またRobinson ら ${ }^{68)}$ は繰返し積層体について分散関係を精密に求め, 弾性論 による厳密解と比較している（図 21）。分散関係および

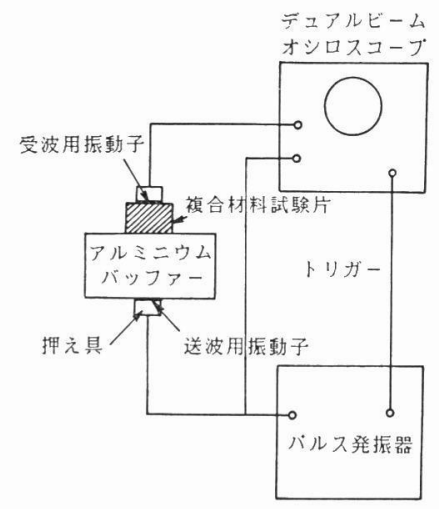

(a)

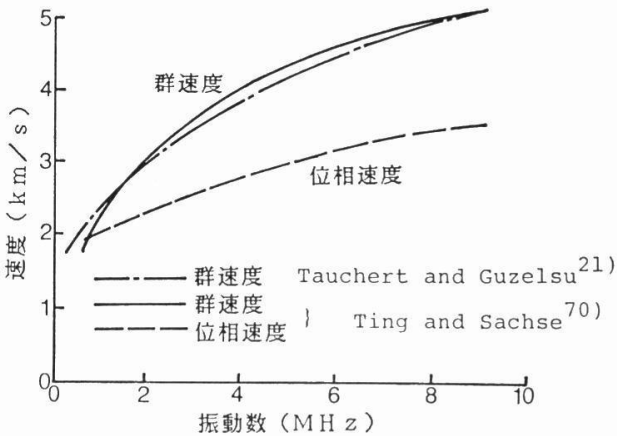

(b)

図 18 (a)Tauchert らの方法21)

固体バッファーを使用. 共振振動数の異なる数組の振動子を用い, パルス状超音波の通過時間を測 定.

(b)ボロン/エポキシ一方向材 $\left(V_{f}=54 \%\right)$ 繊維方向伝播横波の群速度および位相速度-振動数関係 ${ }^{21,70)}$ Achenbach $5^{32)}$ の理論解と類似している. 


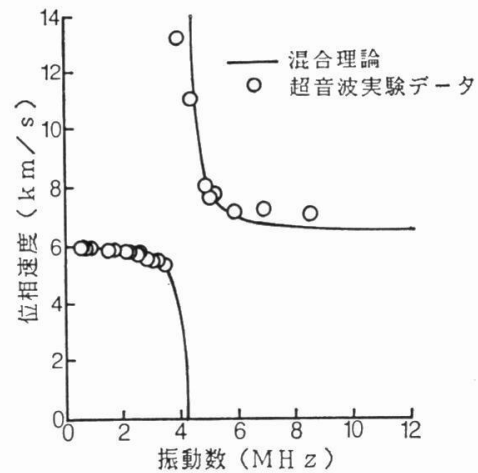

図 19 タングステン/アルミニウム一方向材 $\left(V_{f}=\right.$ $2.2 \%)$ 繊維垂直方向伝播綻波の位相速度-振 動数関係 ${ }^{64,65)}$

混合理論による解とよく一致し, $4 \mathrm{MHz}$ 付近 の遮断振動数域を与えている.

遮断振動数域はきわめてよく一致している.さらに，パ ルスではなく連続波を用いて位相を正確に測定する方法 も Sachse ら ${ }^{69,70)}$ とより提案されており, その結果を図 18(b)に示す。群速度, 位相速度両方が求められており, 群速度については Tauchert らの結果とほぼ一致してい る.

第二に小振幅過渡波を用いる方法である．立上り時間 の短い入射過渡波は, 飛翔体の衝突, 少量の爆薬, 気体 中の衝撃波などによって発生されるが, その振幅は材料 の塑性変形, 破壊を引き起こすほどは大きくなく過渡弾 性波の分散現象が観察でさる ${ }^{66,71)}$. ここではショックチ ニーブを用いた Whittier らの実験66)を紹介する，図 22 (a)に示すように試験片は長いチニーブの中央軸に対して

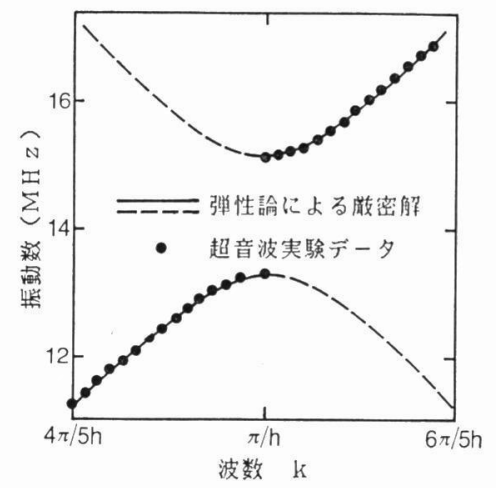

図 21 鋼一銅䈃（どちらも50 $\mu \mathrm{m}$ 厚）繰返し積層 体の積層垂直方向伝播横波の 振動数-波数関 係 ${ }^{68)}$

弾性論による厳密解と実験結果との比較.

垂直に，しかもチューブからは機械的に接触しない状態 で置かれる。気体中を伝播してきた衝撃波は試験片全表 面に継続時間の短いほぼ一次元歪状態の応力波を発生さ せる。 また透過応力波は試験片裏面で容量 ゲージ法 (capacitance gage techniques) によってモニターされ る. 実験結果を波頭近似法による Peck ら ${ }^{42)}$ の理論解析 結果と比較して図 22(b)に示す.

第三に大振幅過渡波を用いる方法であり, 爆薬, 管爆 発, 気体で高速度まで加速された飛び板 (flyer plate) などを用い，第二の方法よりかなり大きな振幅が得られ $3^{72-74)}$. このため継続時間が短くしかも一次元歪状態が 得られる点は同様であるが, 透過波のモニターには水晶 ゲージ, Michelsonまたは変位干渉計, 速度干渉計, 流 しカメラなどが使われる。なかでも飛び板法は最もよく

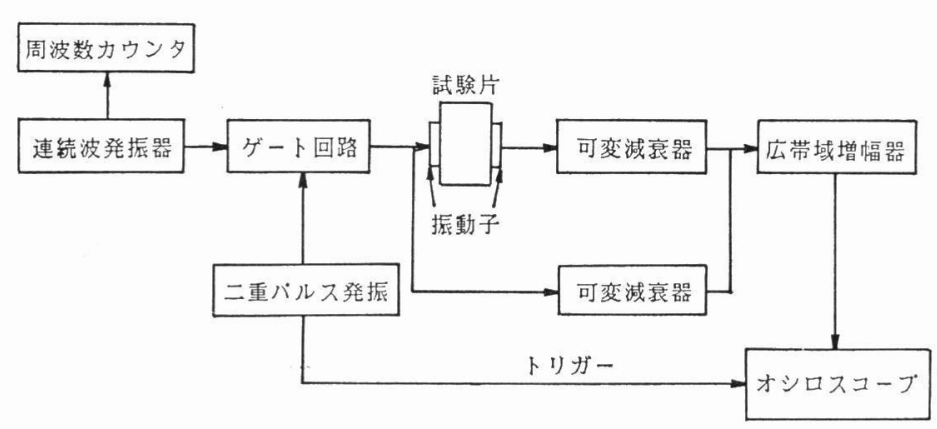

(a)

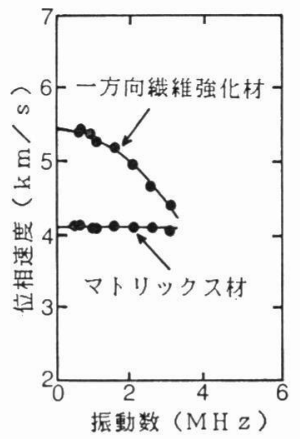

(b)

図 20 (a)Asay 5の方法 ${ }^{67}$

二重パルスを用いたパルス波干渉法.

(b)カーボン/カーボンクロス・フェノール一方向材 $\left(V_{f}=10.5 \%\right)$ 纎維方向伝播縦波の位相速度-振動 数関係 ${ }^{68)}$

マトリックス材のみでは分散はほとんど見られないことに注意. 


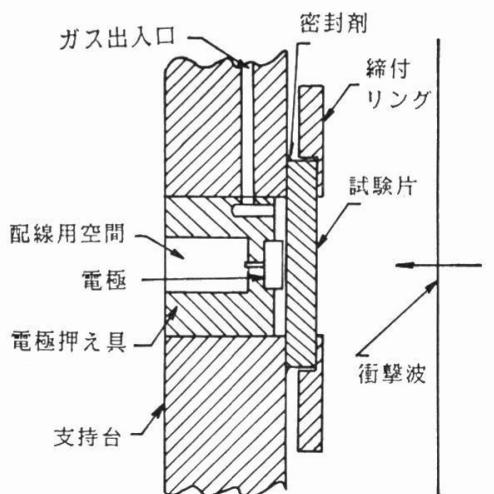

(a)

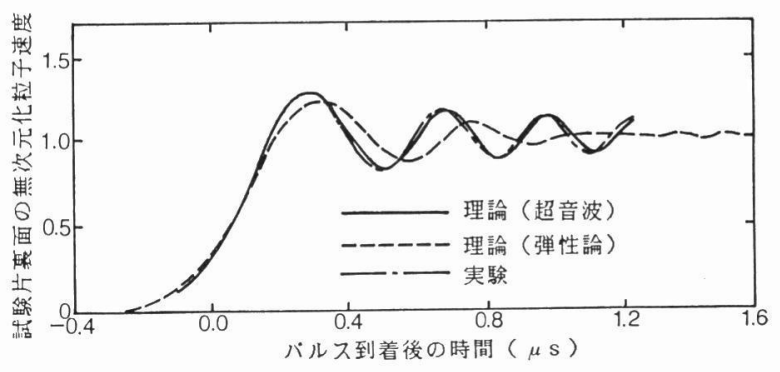

(b)

図 22 (a)ショックチューブを用いたパルス状小振幅応力波伝播実験 ${ }^{66)}$

(b)カーボン/カーボンクロス・フェノールー方向材 $\left(V_{f}=10.5 \%\right)$ 瀻維方向云播パルス状綐波に対す る試験片裏面の速度変化 ${ }^{66)}$

二つの理論値はいずれも波頭近似法によるが，分散関係に弾性論解または超音波測定データのおの 扮のを用いている.

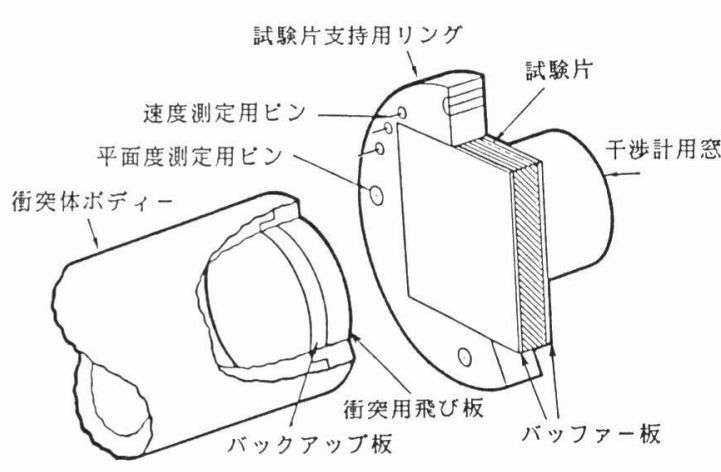

(a)

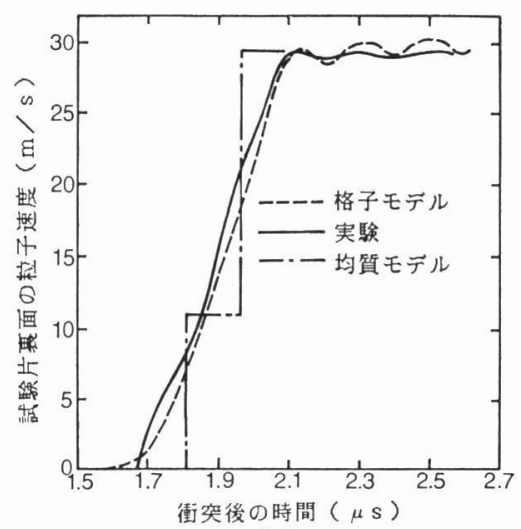

(b)

図 23 (a)飛び板法によるパルス状大振幅応力波伝播実験 ${ }^{72)}$

(b)タングステン/アルミニウム一方向材 $\left(V_{f}=22.1 \%\right)$ 繊維垂直方向伝播パルス状縦波に対する試験片 裏面の速度変化 ${ }^{39}$

理論値は格子モデルによるものと均質理論モデル（弾性波とそれに続く遅い塑性波とから成る）に よるもの ${ }^{122}$.

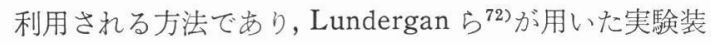
置を図 $23($ a) に示す。実験結果を彼らが提案する格子モ デルによる理論解と比較して図 23(b) に示す ${ }^{39)}$ 。また, 積層板中に接着破壞が生じる場合の実験とその理論解析 も彼らによって行なわれている ${ }^{53,54)}$.

\section{参考文 献}

28) W. Johnson : Impact Strength of Materials, Edward Arnold Ltd., London (1972).

29）河田幸三, 武田展雄: 東大宇航研報告, 14, 3(A) (1978), 857-868.
30) C.T. Sun, J.D. Achenbach \& G. Herrmann : J. Appl. Mech., Trans. ASME, 35, 2 (1968), 408-411.

31) C.T. Sun, J.D. Achenbach \& G. Herrmann : ibid., 35, 3 (1968), 467-475.

32) J.D. Achenbach \& G. Herrmann : AIAA J., 6, 10 (1968), 1832-1836.

33) D.S. Drumheller \& A. Bedford : Int. J. Solids Struct., 10 (1974), 61-76.

34）たと总，熟津久一郎：弾性学の変分原理概論, コンピュータによる構造工学講座 II-3-A, 培風 館, 東京 (1972).

35) A. Bedford \& M. Stern : J. Appl. Mech., Trans. 
ASME, 38, 1 (1971), 8-14.

36) G.A. Hegemier \& A.H. Nayfeh : ibid., 40, 2 (1973), 503-510.

37) W. Kohn, J.A. Krumhansl \& E.H. Lee : ibid., 39, 2 (1972), 327-336.

38) E.H. Lee : Dynamics of Composite Materials, ed. by E.H. Lee, ASME, New York (1972), pp. 122-138.

39) D.S. Drumheller \& H.J. Sutherland : J. $A p p l$. Mech., Trans. ASME, 40, 1 (1973), 149-154.

40) L.M. Barker : J. Compos. Mater., 5 (1971), 140-162.

41) T.C.T. Ting \& I. Mukunoki : J. Appl. Mech., Trans. ASME, 46, 2 (1979), 329-336.

42) J.C. Peck \& G.A. Gurtman : ibid., 36, 3(1969), 479-484.

43) C. Sve : ibid., 37, 1 (1970), 203-205.

44) R.A. Scott : Int. J. Solids Struct., 8 (1972), 833-845.

45) W. Kohn : J. Appl. Mech., Trans. ASME, 41, 1 (1974), 97-100.

46）林 卓夫, 新川和夫, 森本吉春 : 日本航空宇宙学 会誌, 28, 321 (1980), 508-515.

47) C.H. Mok : J. Acoust. Soc. Am., 46, 3(1969), 631-638.

48) J.J. McCoy:J. Appl. Mech., Trans. ASME, 40, 2 (1973), 511-517.

49) R.M. Christensen : ibid., 42, 1 (1975), 153-158.

50) M. Stern, A. Bedford \& C.W. Yew : ibid., 38, 2 (1971), 448-454.

51）田中吉之助, 今野 彰 : 日本機械学会論文集（A 編), 45, 399 (1979), 1418-1425, 1426-1434.

52) T. Hayashi, K. Arakawa \& Y. Morimoto: Composite Materials; Mechanics, Mechanical Properties and Fabrication, ed. by K. Kawata \& T. Akasaka, JSCM, Tokyo (1981), pp. 3946.

53) D.S. Drumheller \& F.R. Norwood : Int. J. Solids Struct., 11 (1975), 53-73.

54) D.S. Drumheller \& C.D. Lundergan : ibid., 11 (1975), 75-87.

55) B.W. Abbott \& L.J. Broutman : Exp. Mech., 6, 7 (1966), 383-384.

56) T.R. Tauchert \& F.C. Moon : $A I A A J ., 9,8$
(1971), 1492-1498.

57) G.E. Nevill, Jr., R.L. Sierakowski, C.A. Ross \& E.R. Jones : Exp. Mech., 12, 6(1972), 278282.

58) C.A. Ross \& R.L. Sierakowski : Shock Vib. Dig. 7, 1 (1975), 1-12.

59) I.M. Daniel, T. Liber \& R.H. LaBedz : Exp. Mech., 19, 1 (1979), 9-16.

60) N. Takeda, R.L. Sierakowski \& L.E. Malvern : J. Compos. Mater., 15 (1981), 157-174.

61) E. Schreiber, O.L. Anderson \& N. Soga : Elastic Constants and Their Measurement, McGraw-Hill, New York (1973), Chap. 3.

62) M.A. Breazeale, J.H. Cantrell, Jr. \& J.S. Heyman : Ultrasonics, ed. by P.D. Edmonds, Methods of Experimental Physics, Vol. 19, Academic Press, Orlando (1981), Chap. 2.

63）高分子学会高分子実験学編集委員会編 : 力学的性 質 II , 共立出版, 東京 (1983), pp. 160-198.

64) H.J. Sutherland \& R. Lingle : J. Compos. Mater., 6 (1972), 490-502.

65) A. Bedford, H.J. Sutherland \& R. Lingle : $J$. Appl. Mech., Trans. ASME, 39, 2(1972), 597598.

66) J.S. Whittier \& J.C. Peck : ibid., 36, 3(1969), 485-490.

67) J.R. Asay, D.L. Lamberson \& A.H. Guenther : J. Acoust. Soc. Am., 45, 3 (1969), 566-571.

68) C.W. Robinson \& G.W. Leppelmeier : J. Appl. Mech., Trans. ASME, 41, 1 (1974), 89-91.

69) W. Sachse \& Y.H. Pao: J. Appl. Phys., 49, 8 (1978), 4320-4327.

70) C.S. Ting \& W. Sachse : J. Acoust. Soc. Am., 64, 3 (1978), 852-857.

71) C. Sve \& S. Okubo : J. Appl. Mech., Trans. $A S M E$, 41, 4 (1974), 1052-1056.

72) C.D. Lundergan \& D.S. Drumheller : Dynamics of Composite Materials, ed. by E.H. Lee, ASME, New York (1972), pp. 35-47.

73) R.P. Reed \& D.E. Munson : J. Compos. Mater., 6 (1972), 232-257.

74) H.J. Sutherland \& D.E. Munson : ibid., 10 (1976), 118-128. 